\title{
VERMICOMPOSTING AS AN ALTERNATIVE WAY OF BIODEGRADABLE WASTE MANAGEMENT FOR SMALL MUNICIPALITIES
}

\author{
Aleksandra Sosnecka', Małgorzata Kacprzak', Agnieszka Rorat ${ }^{1}$ \\ 1 Institute of Environmental Engineering, Czestochowa University of Technology, Brzeznicka 60a Str., 42-200 \\ Czestochowa, Poland, e-mail: mkacprzak@is.pcz.czest.pl
}

Received: 2016.03.16

Accepted: 2016.06.01

Published: 2016.07.01

\begin{abstract}
The aim of the study was to assess the usefulness of vermicomposting as a method of bioconversion of organic wastes, inter alia, sewage sludge, biodegradable fraction of municipal solid wastes and green wastes. Vermicomposting is a biological process in which earthworms are employed to cooperate with microorganisms in order to convert organic wastes into a valuable product. It is considered as a relatively low cost and environmentally-friendly method of waste treatment. Nevertheless, as each biotechnology, the process is limited to some physical, chemical and biological parameters. In this study, sewage sludge coming from medium-sized wastewater treatment plant was mixed with mown grass, sawdust and organic fraction of municipal wastes and vermicomposted for 5 weeks with Eisenia fetida and Eisenia andrei as main actors. The scope of the research was to 1)assess the influence of E. fetida and E.andrei composting earthworms on the physical and chemical properties of the product; 2) changes of concentration of selected heavy metals and their available forms in compost during the process, 3 ) the effects of substrates on earthworms survival and reproduction. Selected earthworm species had shown a high tolerance to the contaminants present in sewage sludge and a positive impact on the quality of the product was noted. Vermicomposting enhances decomposition of organic matter, leads to decrease in $\mathrm{C} / \mathrm{N}$ ratio and $\mathrm{pH}$, and changes the availability of some heavy metals and its total content in substratum. Experimental medium led earthworms to increase body weight due to the presence of large amount of organic matter, while the reproduction was importantly reduced. Vermicomposting can be considered as a method of treatment of solid wastes, mainly in the case of small municipalities.
\end{abstract}

Keywords: vermicomposting, sewage sludge, Eisenia sp., waste management

\section{INTRODUCTION}

Rapid technological development of different industrial branches is inextricably associated with an increasing amount of generated solid wastes, including sewage sludge. The production of this specific waste coming from wastewater treatment plants is enormous and its quantity increases constantly. Though, new strategies of sewage sludge treatment are required. Sewage sludge disposal is one of the major environmental problems in contemporary world. Moreover, sewage sludge or various municipal wastes, i.e. food industry and agricultural wastes, contain large amounts of ingredients that can be used by plants. For some reasons, including pathogens presence, odour nuisance, high heavy metals and other micropollutants content, sewage sludge cannot be used in natural or agricultural purposes. The use of appropriate method of conversion of environmentally harmful wastes allows to receive a valuable fertilizer, rich in nutrients, putatively improving fertility and soil structure [Kucharczak et al. 2010, Łoboda and Wydro 2014, Nowak et al. 2010, Sinha et al. 2010].

Composting, called environmental (natural) utilization, is one of this kind of methods, based on natural processes existing in soil ecosystems. 
Composting is the process of decomposition of organic matter taking place under aerobic conditions and in the presence of numerous microorganisms. During mineralization, basic elements are oxidized mainly to carbon dioxide, sulphates, phosphates and nitrates. After humification process, in which organic compounds are synthesized (humic compounds), compost obtains fertilizing value [Boruszko 2011, Kucharczak et al. 2010, Manczarski 2007].

Another method of sewage sludge utilization is vermicomposting, which can be considered as composting carried out in the earthworms' presence. Earthworms are commonly present in soil, where they are exposed to various contaminants, like heavy metals, pesticides, polycyclic aromatic hydrocarbons (PAH's) [Rorat et al. 2013]. These invertebrates can be used as biomonitoring tools in ecotoxicology, because they tend to show morphological or physiological changes due to variations in physical and chemical conditions of their living environment [Rorat et al. 2014]. One of the most popular and commonly used species of composting earthworms is Eisenia fetida, characterized by long life cycle, high fertility and high tolerance to changing environmental factors [Dominguez and Edwards 2011]. Thus, vermicomposting enables biological transformation of wastes into valuable organic fertilizer [Bożym 2012, Kostecka 2000].

Nevertheless, organic fertilizers, produced in composting and vermicomposting processes must meet standards imposed by law, especially Act of 10 July 2007 on fertilisers and fertilising [Act 2007], to be disposed in natural or agricultural ways . They must be free from pathogens and contain permissible level of contaminants, cannot be harmful for the environment, wildlife and humans [Bień et al. 2011b].

The aim of this study was to determine the influence of composting earthworm species Eisenia fetida and Eisenia andrei on the properties of final product of vermicomposting process carried out on sewage sludge as main ingredient. Changes in heavy metals content, such as $\mathrm{Cd}, \mathrm{Cr}, \mathrm{Cu}, \mathrm{Ni}$, $\mathrm{Pb}, \mathrm{Zn}$ and their forms of occurrence were examined. Furthermore, changes of selected physical - chemical parameters of product during the vermicomposting process was determined. The survival and reproduction of composting earthworms after vermicomposting process was also assessed.

\section{MATERIALS AND METHODS}

\section{Earthworms}

Adult (clitelled) composting earthworms Eisenia fetida and Eisenia andrei were used. Animals were transported from breeding culture belonging to the Université de Lille Nord du France, Laboratoire Génie Civile et géoEnvironment. They were kept in plastic boxes measuring 198x198x99mm (length $\times$ width $\times$ height) with perforated lids in laboratory conditions in Institute of Environmental Engineering at Czestochowa University of Technology. They were fed with brewed tea leaves once a week.

\section{Sewage sludge}

Dewatered sewage sludge, the main component of compost, was obtained from a medium-sized wastewater treatment plant with capacity $\mathrm{Q}=90000 \mathrm{~m}^{3}$, and $\mathrm{ENI}=315000$ (Equivalent Number of Inhabitants measured as the ratio of the sum of the pollution load produced during $24 \mathrm{~h}$ by industrial facilities and services to the individual pollution load in household sewage produced by one person in the same time). Sewage sludge was characterized by pH $7.08\left(\mathrm{H}_{2} \mathrm{O}\right), \mathrm{N} 19.32 \mathrm{~g} \mathrm{~kg}^{-1}$ d.m., TC $330.4 \mathrm{~g} \mathrm{~kg}^{-1}$ d.m., Cd $5.64 \mathrm{mg} \mathrm{g} \mathrm{g}^{-1}$ d.m., $\mathrm{Pb} 136.1$ mg kg-1.m., Zn 1464 mg kg ${ }^{-1}$ d.m. Sludge was transported to Institute of Environmental Engineering where the experiment started immediately.

\section{Compost}

The vermicomposting process was carried out in the Institute of Environmental Engineering at Czestochowa University of Technology. The percentage composition of compost is shown in Table 1.

Table 1. The percentage composition of composting mixture [Bień et al. 2011a]

\begin{tabular}{|l|c|}
\hline \multicolumn{1}{|c|}{ Component } & Content (\%) \\
\hline Sewage sludge & 45 \\
\hline Mown grass & 35 \\
\hline Organic fraction of municipal waste & 10 \\
\hline Sawdust & 10 \\
\hline
\end{tabular}




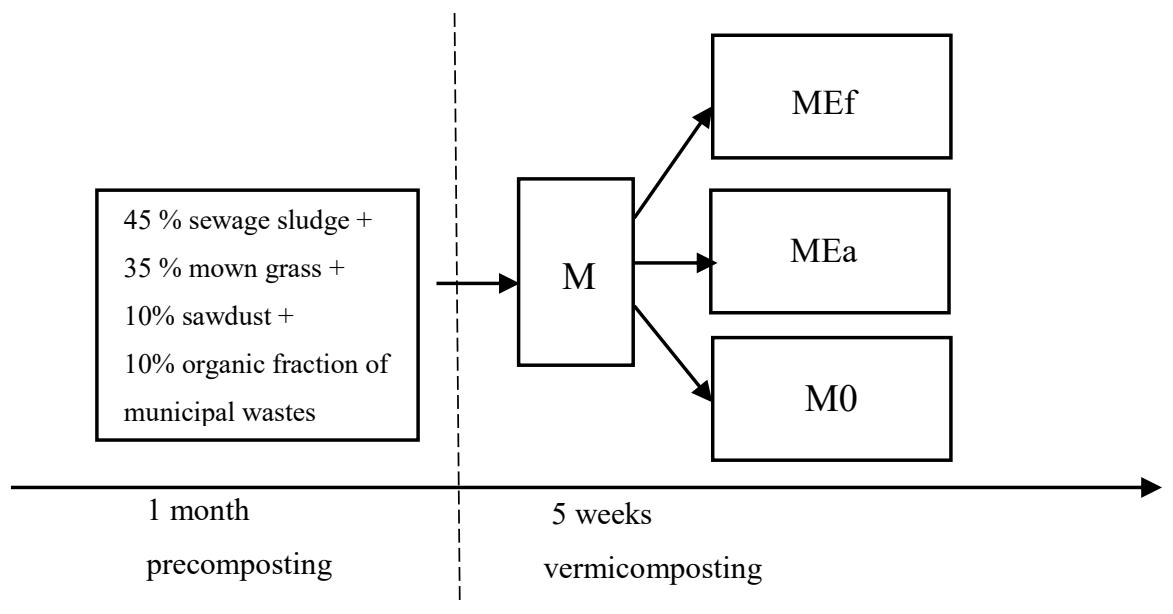

Figure 1. Experimental design: $\mathrm{M}$ - mixture before vermicomposting, MEf - mixture with Eisenia fetida, $\mathrm{MEa}$ - mixture with Eisenia andrei, M0 - mixture without earthworms (control).

\section{Experimental design}

A study was carried out in a laboratory of the Institute of Environmental Engineering at Czestochowa University of Technology during 5 weekperiod. Firstly, $500 \mathrm{~g}$ of compost was put into six prepared plastic boxes and $500 \mathrm{~g}$ of control soil (mix of garden soil and brewed tea leaves in the ratio of 9:1) into another 3 plastic boxes. Then, Eisenia fetida and Eisenia andrei adults were introduced separately into boxes, 10 individuals per box with compost and with control soil. All boxes were covered with perforated lids in triplicates. The experimental design is shown on the Figure 1. Control soil supplemented with brewed tea leaves was a reference sample for verifying the parameters of the vermicomposting process.

\section{Methods}

Different physical and chemical parameters were examined in samples taken before and after 5 weeks of the experiment: total solids (TS) [APHA 1999], pH [PN-ISO10390:1997] using digital pH meter (Cole Parmer Model No. 5900200), total Kjeldahl nitrogen [PN-ISO11261:2002], total carbon [PN-ISO10694:2002] using a Multi N/C 2100 Analityk Jena, C/N ratio, bioavailable phosphorus[PN-R-04023:1996]. A total amount of $100 \mathrm{~g}$ was collected from each vermireactor using multi-point sampling conducted at random. The samples were dried at $60{ }^{\circ} \mathrm{C}$ in a ventilated oven for $48 \mathrm{~h}$ and then homogenized by grinding into small pieces using $\mathrm{IKA}^{\circledR}$ A11 basic analytical mill as described previously [Rorat et al. 2015]. Total heavy metals content and content of their bioavailable forms were also defined. Bioavailable forms of selected heavy metals were extracted using $0.01 \mathrm{M} \mathrm{CaCl}_{2}$. Total heavy metals were measured by inductively coupled plasma optical emission spectrometry (ICP-OES; Thermo apparatus) after digesting of $250 \mathrm{mg}$ of sample with $8 \mathrm{~mL}$ of concentrated HNO3. Samples were digested using microwave digestion. As an environmental matrix, the following reference materials were used: LGCQC3004 (soil material) and BCR-146R (sewage sludge material).

\section{RESULTS AND DISCUSSION}

Results are represented as arithmetic mean of three replicates. The differences between the obtained values were determined by one-way ANOVA with Tukey's post-hoc test at confidence level $\mathrm{p}<0,05$.

In the study a $100 \%$ survival was observed for both species of composting earthworms, Eisenia fetida and Eisenia andrei, in compost and control soil samples as well. After five weeks of the experiment earthworms' reproduction was determined, based on the number of cocoons and juveniles (Table 2).

The results indicate that both species of earthworms show much higher reproduction in samples supplemented with brewed tea leaves soil (which is a control) than in compost. This phenomenon may be explained by a well-known "trade-off" mechanism, according to which the optimal living conditions prompted the earthworms to increase the reproduction rate and to maintain the approximate weight [Brulle et al. 2006]. On the other 
Table 2. Reproduction of composting earthworms

\begin{tabular}{|l|c|c|c|c|}
\hline \multicolumn{1}{|c|}{ Earthworms } & \multicolumn{2}{|c|}{ Control soil } & \multicolumn{2}{c|}{ Compost } \\
\hline & cocoons & juveniles & cocoons & juveniles \\
\hline Eisenia fetida & 76 & 211 & 1 & 0 \\
\hline Eisenia andrei & 11 & $>300$ & 5 & 0 \\
\hline
\end{tabular}

hand, the experimental medium (supplemented soil) led earthworms to increase body weight due to presence of large amount of organic matter.

The analysis of total heavy metals concentration and content of bioavailable forms were performed before and after the process, both in compost and control soil samples. The results are shown in tables below: changes in total heavy metal content in table 3 and in bioavailable heavy metals content in Table 4.

Total concentration of heavy metals tends to increase in all examined conditions. Nevertheless, only in the case of few metals in selected samples, such as $\mathrm{Cu}$ (after 5 weeks of process with Eisenia fetida) and Zn (after 5 weeks of process with Eisenia andrei and without earthworms), results were statistically different, according to one-way ANOVA with Tukey's posthoc test. According to many sources [Elvira et al. 1997, Hait and Tare 2011] these increases are due to reduction of weight and volume of biomass in the vermicomposting process.

A decrease in concentration of bioavailable Cd was noticed in Eisenia fetida presence in contrast to the Eisenia andrei species. Decrease in currently soluble forms of $\mathrm{Cr}$ and $\mathrm{Ni}$ was observed. It is probably caused by composting process, not only because of earthworm presence. According to authors [Hait and Tare 2012] decrease in the concentration of currently soluble form of $\mathrm{Cr}$ is due to reduction of this element by biological organisms.

Table 5 shows changes in selected physical and chemical parameters of compost during vermicomposting process in Eisenia fetida and Eisenia andrei presence.

According to the obtained results, $\mathrm{pH}$ oscillated between 6.48-6.66. Yadav and Garg [2011] indicated the optimal $\mathrm{pH}$ range for the vermicomposting process: 5.5-8.5. Thus, experimental $\mathrm{pH}$ is within this range. During vermicomposting process $\mathrm{pH}$ decrease can be observed, due to mineralization of phosphorus to orthophosphates and nitrogen to nitrates and nitrites. As another reason of environment alkalization authors report bioconversion of organic matter to intermediates of organic acids. In experiment carried out $\mathrm{pH}$ did not change importantly [Ndegwa et al. 2000, Yadav and Garg 2011].

Table 3. Changes in total heavy metals content $\left(\mathrm{mg} \mathrm{kg}^{-1}\right)$

\begin{tabular}{|c|c|c|c|c|c|c|c|}
\hline Time [weeks] & & $\mathrm{Cd}$ & $\mathrm{Cr}$ & $\mathrm{Cu}$ & $\mathrm{Ni}$ & $\mathrm{Pb}$ & $\mathrm{Zn}$ \\
\hline 0 & $\mathrm{M}$ & 1.71(0.40)a & 152.24(7.63)a & 136.4(7.13)a & 79.2(2.04)a & 62.78(10.50)a & 753.67(11.00)a \\
\hline \multirow{3}{*}{5} & $\mathrm{MEf}$ & 1.74(0.14)a & 162.38(10.02)a & 228.47(111.3)b & 90.89(4.08)a & 71.97(5.24)a & 891.73(35.48)ab \\
\cline { 2 - 8 } & $\mathrm{MEa}$ & 1.85(0.19)a & 155.67(35.03)a & 152.39(8.18)ab & 94.8(16.09)a & 68.09(9.81)a & 955.53(112.25)b \\
\cline { 2 - 8 } & $\mathrm{M} 0$ & 1.86(0.23)a & 163.695(9.36)a & 156.77(9.20)ab & 94.74(11.89)a & 76.185(14.82)a & 973.635(96.29)b \\
\hline
\end{tabular}

$\mathrm{M}$ - mixture before vermicomposting, MEf - mixture with Eisenia fetida, MEa - mixture with Eisenia andrei, M0 - mixture without earthworms (control). Results shown as means (SD), results not sharing the same letters in columns are statistically different according to one-way ANOVA with Tukey's post-hoc test.

Table 4. Changes in bioavailable heavy metals content $\left(\mathrm{mg} \mathrm{kg}^{-1}\right)$

\begin{tabular}{|c|c|c|c|c|c|c|c|}
\hline Time [weeks] & & $\mathrm{Cd}$ & $\mathrm{Cr}$ & $\mathrm{Cu}$ & $\mathrm{Ni}$ & $\mathrm{Pb}$ & $\mathrm{Zn}$ \\
\hline 0 & $\mathrm{M}$ & $0.03(0.01) \mathrm{a}$ & $0.06(0.01) \mathrm{a}$ & $1.37(0.12) \mathrm{a}$ & $1.47(0.05) \mathrm{a}$ & $0.11(0.02) \mathrm{a}$ & $5.86(0.38) \mathrm{a}$ \\
\hline \multirow{3}{*}{5} & $\mathrm{MEf}$ & $0.02(0.00) \mathrm{b}$ & $0.05(0.00) \mathrm{ab}$ & $1.09(0.09) \mathrm{a}$ & $1.12(0.06) \mathrm{b}$ & $0.12(0.04) \mathrm{a}$ & $4.79(0.16) \mathrm{b}$ \\
\cline { 2 - 9 } & $\mathrm{MEa}$ & $0.02(0.00) \mathrm{c}$ & $0.04(0.00) \mathrm{b}$ & $1.21(0.08) \mathrm{a}$ & $1.28(0.13) \mathrm{ab}$ & $0.16(0.03) \mathrm{a}$ & $6.76(0.18) \mathrm{a}$ \\
\cline { 2 - 9 } & $\mathrm{M} 0$ & $0.03(0.01) \mathrm{a}$ & $0.04(0.00) \mathrm{b}$ & $2.99(0.11) \mathrm{a}$ & $1.26(0.38) \mathrm{ab}$ & $0.125(0.00) \mathrm{a}$ & $6.79(0.65) \mathrm{a}$ \\
\hline
\end{tabular}

M - mixture before vermicomposting, MEf - mixture with Eisenia fetida, MEa - mixture with Eisenia andrei, M0 - mixture without earthworms (control). The results shown as means (SD), results not sharing the same letters in columns are statistically different according to one-way ANOVA with Tukey's post-hoc test. 
Table 5. Changes in selected physical and chemical parameters of compost during vermicomposting process

\begin{tabular}{|c|c|c|c|c|c|}
\hline Time [weeks] & & TS [\%] & $\mathrm{pH}$ & $\mathrm{P}_{2} \mathrm{O}_{5}\left(\mathrm{mg} \mathrm{kg}^{-1}\right)$ & $\mathrm{C} / \mathrm{N}$ \\
\hline 0 & $\mathrm{M}$ & $26.32(1.44) \mathrm{a}$ & $6.54(0.25) \mathrm{ab}$ & $294.75(4.71) \mathrm{ab}$ & $20.58(1.92) \mathrm{a}$ \\
\hline \multirow{3}{*}{5} & $\mathrm{MEf}$ & $26.39(1.07) \mathrm{a}$ & $6.81(0.10) \mathrm{a}$ & $308.25(2.89) \mathrm{a}$ & $19.99(2.64) \mathrm{a}$ \\
\cline { 2 - 6 } & $\mathrm{MEa}$ & $28.06(1.04) \mathrm{a}$ & $6.48(0.06) \mathrm{b}$ & $302.72(2.48) \mathrm{ab}$ & $16.44(2.32) \mathrm{b}$ \\
\cline { 2 - 6 } & $\mathrm{M}$ & $26.06(2.91) \mathrm{a}$ & $6.66(0.06) \mathrm{ab}$ & $275.32(1.21) \mathrm{b}$ & $16.26(1.36) \mathrm{b}$ \\
\hline
\end{tabular}

M - mixture before vermicomposting, MEf- mixture with Eisenia fetida, MEa - mixture with Eisenia andrei, M0 - mixture without earthworms (control). Results shown as means (SD), results not sharing the same letters in columns are statistically different according to one-way ANOVA with Tukey’s post-hoc test.

The content of bioavailable phosphorus increased in compost samples in Eisenia fetida presence, while in Eisenia andrei presence a slight decrease was observed. According to Yadav and Garg [2009] and Zhu et al. [2016] the increase of bioavailable phosphorus content during vermicomposting process is the result of mineralization and phosphorus mobilization, but also alkaline phosphatase activity, which is excreted by composting worms.

The crucial parameter, determining the correct process is carbon to nitrogen ratio. Rostami et al. [2010] report that elevated level of $\mathrm{C} / \mathrm{N}$ ratio can affect the microbial activity, while its reduction may cause an increase of releasing ammonia to atmosphere. The vermicomposting process leads to the decrease of $\mathrm{C} / \mathrm{N}$ ratio. According to Zhu et al. [2016] this is due to a decomposition of organic matter. Moreover, a decrease of carbon content, used by organisms as energy source, and an increase in nitrogen concentration, which is mineralized can also explain this relation [Yadav and Garg 2011].

\section{CONCLUSIONS}

1. Composting earthworm species: Eisenia fetida and Eisenia andrei are resistant to the contaminants present in sewage sludge and they have a positive impact on the quality of the final product.

2. Vermicomposting affects the heavy metal content in the composting mixture.

3. Earthworm species (Eisenia fetida and Eisenia andrei) affect the product by shifting the concentration of current soluble forms of heavy metals, in this case heavy metals accumulation and their incorporation to trophic system is possible.

4. Vermicomposting can be considered as a method of solid wastes and the obtained product (vermicompost) can be used as a fertilizer, if it meets standards imposed by law, especially act on fertilizers and fertilization.

\section{Acknowledgements}

The research leading to these results has received funding from the Polish-Norwegian Research Programme operated by the National Centre for Research and Development under the Norwegian Financial Mechanism 20092014 in the frame of Project Contract No (POL NOR/201734/76)

\section{REFERENCES}

1. Act, 2007. Act of 10th July 2007 on fertilisers and fertilising (Dz.U. $2007 \mathrm{nr} 147$ poz. 1033 with later amendments).

2. APHA, 1999. Standard Methods for the Examination of Water and Wastewater, 20th edition, Washington, DC.

3. Bień, J., Milczarek, M., Neczaj, E., Worwąg, M., Okwiet, T., Kowalczyk, M., 2011a. Composting process as an alternative method for the disposal of sewage sludge and organic fraction of municipal solid waste. Civil and Environmental Engineering Reports, 127-136.

4. Bień, J., Neczaj, E., Worwąg, M., Grosser, A., Nowak, D., Milczarek, M., Janik, M., 2011b. Kierunki zagospodarowania osadów w Polsce po roku 2013. Inżynieria i Ochrona Środowiska 14, 375-384.

5. Boruszko, D., 2011. Badania i ocena wartości nawozowej kompostów i wermikompostów. Rocznik Ochrona Środowiska, 1417-1428.

6. Bożym, M., 2012. Biologiczne przetwarzanie biodegradowalnej frakcji odpadów komunalnych i osadów ściekowych w wermikulturze. Prace Instytutu Ceramiki i Materiałów Budowlanych 5, 335-369.

7. Brulle, F., Mitta, G., Cocquerelle, C., Vieau, D., Lemiere, S., Lepretre, A., Vandenbulcke, F., 2006. 
Cloning and real-time PCR testing of 14 potential biomarkers in Eisenia fetida following cadmium exposure. Environmental Science and Technology 40, 2844-2850.

8. Dominguez, J., Edwards, C.A., 2011. Biology and Ecology of Earthworm Species Used for Vermicomposting, in: Clive A . Edwards, N.Q.A., Rhonda L. Sherman (Ed.), Vermiculture technology: earthworms, organic wastes, and environmental management. CRC Press USA.

9. Elvira, C., Sampedro, L., Benftez, E., Nogales, R., 1997. Vermicomposting of sludges from paper mill and dairy industries with eisenia andrei: a pilotscale-study. Bioresour Technol 63, 205-211.

10. Hait, S., Tare, V., 2011. Vermistabilization of primary sewage sludge. Bioresour Technol 102, 2812-2820.

11. Hait, S., Tare, V., 2012. Transformation and availability of nutrients and heavy metals during integrated composting-vermicomposting of sewage sludges. Ecotoxicol Environ Saf 79, 214-224.

12. Kostecka, J., 2000. Badania nad wermikompostowaniem odpadów organicznych. Zeszyty Naukowe Akademii Rolniczej w Krakowie. Rozprawy 268, 1-88.

13. Kucharczak, K., Stepien, W., Gworek, B., 2010. Kompostowanie odpadów komunalnych jako metoda odzysku substancji organicznej. Ochrona Środowiska i Zasobów Naturalnych.

14. Łoboda, T., Wydro, U., 2014. Główne problemy związane $\mathrm{z}$ zagospodarowaniem komunalnych osadów ściekowych. Inżynieria środowiska Młodym okiem 5, Ścieki i osady ściekowe, 97-116.

15. Manczarski, P., 2007. Kompostowanie odpadów komunalnych, Referat na Forum Technologii Ochrony Środowiska-POLEKO, Poznań, p. 2007.

16. Ndegwa, P.M., Thompson, S.A., Das, K.C., 2000. Effects of stocking density and feeding rate on vermicomposting of biosolids. Bioresource Technology $71,5-12$.

17. Nowak, M., Kacprzak, M., Grobelak, A., 2010. Osady ściekowe jako substytut glebowy w procesach remediacji i rekultywacji terenów skażonych metalami ciężkimi. Inżynieria i Ochrona Środowiska 13, 121-131.

18. PN-ISO10390:1997, Soil quality. Determination of $\mathrm{pH}$.
19. PN-ISO10694:2002, Soil Quality. Determination of organic and total carbon after dry combustion ('elementary analysis').

20. PN-ISO11261:2002, Soil Quality - Determination Of Total Nitrogen - Modified Kjeldahl Method.

21.PN-R-04023:1996., Chemical-physical soil analsis. Determination of available phosphorus in mineral soils.

22. Rorat, A., Kachamakova-Trojanowska, N., Jozkowicz, A., Kruk, J., Cocquerelle, C., Vandenbulcke, F., Santocki, M., Plytycz, B., 2014. Coelomocytederived fluorescence and DNA markers of composting earthworm species. J Exp Zool A Ecol Genet Physiol 321, 28-40.

23. Rorat, A., Kacprzak, M., Vandenbulcke, F., Płytycz, B., 2013. Soil amendment with municipal sewage sludge affects the immune system of earthworms Dendrobaena veneta. Applied Soil Ecology 64, 237-244.

24. Rorat, A., Suleiman, H., Grobelak, A., Grosser, A., Kacprzak, M., Płytycz, B., Vandenbulcke, F., 2015. Interactions between sewage sludge-amended soil and earthworms - comparison between Eisenia fetida and Eisenia andrei composting species. Environ Sci Pollut Res 23, 3026-3035.

25. Rostami, R., Nabaei, A., Eslami, A., Najafi, S.H., 2010. Survey of $E$. foetida population on $\mathrm{pH}, \mathrm{C} / \mathrm{N}$ ratio and process's rate in vermicompost production process from food wastes.

26. Sinha, R.K., Herat, S., Bharambe, G., Brahambhatt, A., 2010. Vermistabilization of sewage sludge (biosolids) by earthworms: converting a potential biohazard destined for landfill disposal into a pathogen-free, nutritive and safe biofertilizer for farms. Waste Manag Res 28, 872-881.

27. Yadav, A., Garg, V.K., 2009. Feasibility of nutrient recovery from industrial sludge by vermicomposting technology. J Hazard Mater 168, 262-268.

28. Yadav, A., Garg, V.K., 2011. Industrial wastes and sludges management by vermicomposting. Reviews in Environmental Science and Bio/Technology 10, 243-276.

29. Zhu, W., Yao, W., Du, W., 2016. Heavy metal variation and characterization change of dissolved organic matter (DOM) obtained from composting or vermicomposting pig manure amended with maize straw. Environ Sci Pollut Res, 1-12. 